Nelson, D.R. (1997). Intussusception in cattle: 336 cases (1964-1993). Journal of the American Veterinary Medical Association 210: 531-536. Dabak, M., Unsaldi, E. and Gul, Y. (2001). Diagnosis and treatment of intussusception in a cow. Turkish Journal of Veterinary Animal Science 25: 387-389.

Edens, L.M., White, N.A., Dabareiner, R.M. and Sullins, K.E. (1996).

Transrectal ultrasonographic diagnosis of an ileocaecal intussusception in a horse. Equine Veterinary Journal 28: 81-83.

Ein, S.H. and Stephens C.A. (1971). Intussusception: 354 cases in 10 years. Journal of Pediatric Surgery 6: 16-27.

Fontaine-Rodgerson, G. and Rodgerson, D.H. (2001). Diagnosis of small intestinal intussuception by transabdominal ultrasonography in 2 adult horses. Canadian Veterinary Journal 42: 378-380.

Ford, T.S., Freeman, D.E., Ross, M.W., Richardson, D.W., Martin, B.B. and Madison, J.B. (1990). Ileocecal intussusception in horses: 26 cases (1981-1988). Journal of the American Veterinary Medical Association 196: 121-126.
Lewis, D.D. and Ellison, G.W. (1987). Intussusceptions in dogs ang cats. Compendium on Continuing Education for the Practicing Veterinarian 9: 523-533

Pearson, H. and Pinsent, H,J. (1977). Intestinal obstruction in cattle. Veterinary Record. 101: 162-166.

Smith, D.F. (1980). Intussusception in adult cattle. Compendium on Continuing Education for the Practicing Veterinarian - Large Animal Supplements 11: S49-S53.

Smith, D.F. (1984). Bovine intestinal surgery: Part 3. Modern Veterinary Practice 65: 909-912.

Smith, D.F. (1985). Bovine intestinal surgery: Part 5. Modern Veterinary Practice 66: 405-409.

Smith D.F. (1990). Surgery of the bovine small intestine. Veterinary Clinics of North America Food Animal Practice 6: 449-60.

Pearson, H. (1971). Intussusception in cattle. Veterinary Record 89: 426-437. Robertson, J.T. (1979). Differential diagnosis and surgical management of intestinal obstruction in cattle. Veterinary Clinics of North America Large Animal Practice 1: 377-394.

\title{
Vaginal fibrosarcoma in a cow
}

B. Musal, P. Ulutas, A. Aydogan

Faculty of Veterinary Medicine, Adnan Menderes University, Isikli - Aydin, Turkey

Corresponding author: B. Musal. Tel: +90 2562470700

Email: bmusal@adu.edu.tr

Irish Veterinary Journal Volume 60 Number 7, 424-425, 2007

Vaginal fibrosarcomas are unusual mesenchymal tumours in cows. This report describes the clinical investigation, gross and histopathological findings, surgical treatment and postoperative course of a vaginal fibrosarcoma in a cow.

Fibropapillomas are the most commonly encountered type of tumours in the vagina and vulva of the cow. They are usually pedunculated and can be removed surgically. Although they do not cause infertility, they may be associated with dystocia (Noakes, 1996). Besides fibropapillomas, cases of squamous cell carcinoma, leiomyoma, fibroma, haemangioma, leiomyosarcoma and melanoma have also been reported in the vagina and vulva of cows (Yeruham et al., 1999). Fibrosarcomas can be found in any location of the body. However, they are unusual mesenchymal tumours of the bovine vagina (Kokuuslu et al., 1980; Deveci et al., 1988; Moulton, 1990). Fibromas, fibro-papillomas and fibrosarcomas have been reported as mushroom-shaped growths, and can be attached either by a broad base or by a long pedicle that allows part of the tumour to protrude from the vulva (Yeruham et al., 1999).

An eight-year-old Holstein Freisian cow was admitted for the evaluation of a pedunculated vaginal mass that was attached to the right lateral vaginal wall and partially protruded from the vagina (Figure 1). The mass had a wet surface with a mucoid, sanguinous discharge. Appetite was normal and the general physical examination revealed no other abnormalities.
Haematological examination prior to surgery revealed a leucocytosis. The total WBC count was elevated to 16.1 cells $/ \mu \mathrm{L}$ (range 4-12), with a high neutrophil count of 8090 cells/ $\mu \mathrm{L}$ (range 600-4000) and a lymphocyte count at the high end of physiological normal $(7490$ cells/ $\mu \mathrm{L}$; range 2500-7500). Other parameters, such as RBC, HGB and HCT were slightly below physiological range, which may be an indicator of mild anaemia due to the continuous haemorrhagic discharge from the mass. Serum biochemistry showed minor increases in ALT and creatinine but AST, total protein, triglycerides, phosphorus and AST were all within the normal range.

The cow was restrained and the tail bandaged. Local epidural anaesthesia was performed with the administration of $8 \mathrm{ml}$ of $2 \%$ lidocaine (Jetokain; Adeka, Turkey).

Additional local infiltration anaesthesia, within the vaginal mucosa surrounding the pedicle of the tumoral mass, was performed with the same anaesthetic agent using a volume of approximately $15-20 \mathrm{ml}$. Following anaesthesia, the vulva was retracted from either side with uterine forceps and the mass was revealed. An oval incision was made on the mucoasl surface at a distance of approximately $2 \mathrm{~cm}$ from the margin of the mass. The total length of incision was $15 \mathrm{~cm}$. Following this, blunt dissection with scissors was used to increase the depth of the incision without interfering with the edge of the mass. The major blood vessels were ligated where necessary. The defect created after the removal of the 


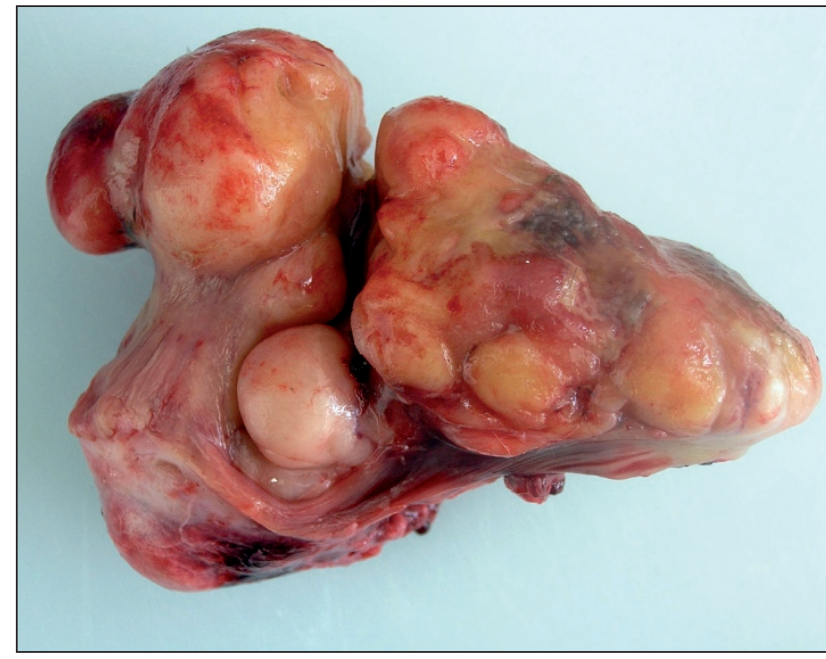

Figure 1: Nodular appearance of the tumoral mass.

mass was closed in two steps. Firstly, interrupted cruciate sutures were applied and, secondly, these were supported with a superficial continuous suture pattern, both using a chromic gut of USP size 2. Postoperative parenteral antibiotics (Clemipen-Strep; Topkim, Turkey) for four days and local wound healing agents (Bepanthene plus; Roche, Turkey) were administered daily for two weeks.

For structural differentiation, the tumoral mass was fixed in $10 \%$ formalin solution, routinely paraffin-embedded, sectioned at $4-5 \mu$ and stained with haematoxylin-eosin $(\mathrm{H} \& \mathrm{E})$ stain. Sections were stained with van Gieson's and Masson's trichrome stains for the detection of collagen fibers (Luna, 1968; Meuten, 2002). Macroscopically, the tumoral mass was located on the ventral vaginal wall. It was $12 \mathrm{~cm}$ $\mathrm{x} 6 \mathrm{~cm} \times 4 \mathrm{~cm}$ in size, weighed $244 \mathrm{~g}$, was greyish-yellow in colour, firm to the touch and had a nodular appearance (Figure 1). The cut surface was homogeneously white in colour.

Microscopically, the tumour was composed of spindleshaped tumour cells forming interlacing bundles or arranged in herringbone patterns. The cells had marked cellular pleomorphism with oval or round and slightly hyperchromatic, nuclei with abundant eosinophilic cytoplasm. Mitotic figures were common and multinucleated giant cells were generally observed (Figure 2). The stroma of the tumour was made up of collagen fibres which were detected by van Gieson's and Masson's trichrome stains. According to these histopathological findings, the tumour was diagnosed as a fibrosarcoma. In contrast to a fibropapilloma, the tumour did not consist of proliferating fibrous tissue with an epithelial covering of variable thickness.

The cow was examined two weeks after the operation, and excellent wound healing was observed with no evidence of postoperative infection. A further examination was performed following a six-month period, no evidence of regrowth of any tumoral tissue could be found and the general condition of the cow was normal. This suggests that

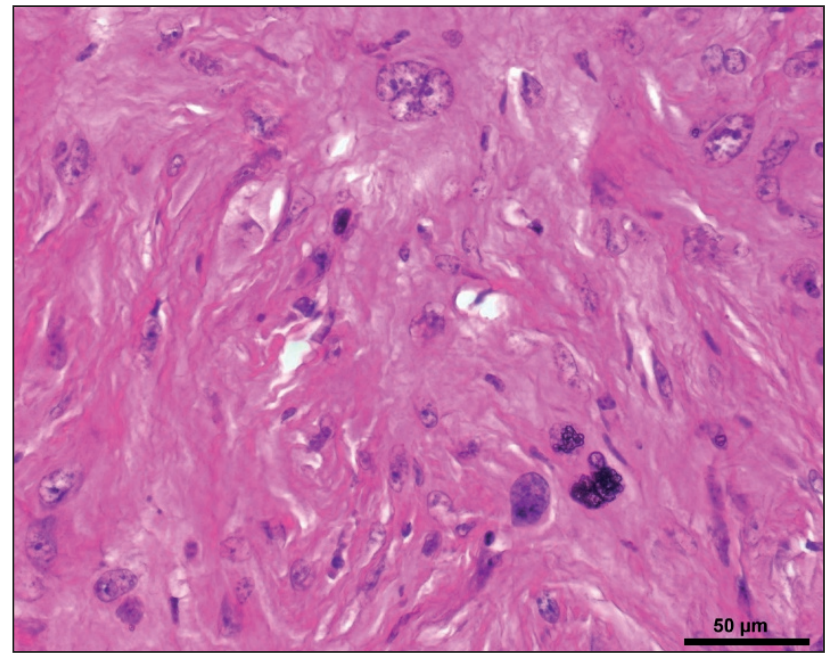

Figure 2: Fibrosarcoma with marked cellular pleomorphism and multinucleated giant cell. Haemotoxylin and Eosin. Original magnification x 480 .

a favourable prognosis may be expected following proper extirpation of pedunculated tumoral masses in cows.

\section{References}

Deveci, H., Tirmukan, H. and Çiftçi, M. K. (1988). Bir inek vaginasinda fibrosarkom olgusu. Selcuk Univ. Vet. Fak. Derg. 4 (1): 381-385.

Kokuuslu, C., Erer, H. and Unsal, E.F. (1980). Ineklerde vulva ve vagina tumorleri. Ankara Univ. Vet. Fak. Derg. 27 (3-4): 431-439.

Luna, G. L. (1968). Histological Staining Methods of the Armed Forces Institute of Pathology. US: Mcgraw Hill Book Company.

Meuten, D. J. (2002). Tumors in Domestic Animals. 4th edition. Iowa Iowa State Press.

Moulton, J. E. (1990). Tumors in Domestic Animals. 3rd edition. California: University of California Press.

Noakes, D.E. (1996). Infertility in the cow: General considerations, anatomical, functional and management causes. In: G.H. Arthur, D.E. Noakes, H. Pearson and T.J. Parkinson (eds.) Veterinary Reproduction and Obstetrics. Philadelphia: WB Saunders. pp 345-388.

Yeruham, I., Perl, S., Orgad, U. and Yakobson, B. (1999). Tumours of the vulva and vagina in cattle - a 10-year survey. The Veterinary Journal 158: 237-239. 